\title{
Anti-PKN3 siRNA Atu027
}

National Cancer Institute

\section{Source}

National Cancer Institute. Anti-PKN3 siRNA Atu027. NCI Thesaurus. Code C84847.

A lipoplexed formulation consisting of short-interfering RNAs (siRNAs) directed ag ainst protein kinase N3 (PKN3) encapsulated in catiogenic and fusiog enic lipids with potential antineoplastic activity. Upon administration, catiog enic and fusiog enic lipids promote antiPKN3 siRNA Atu02 uptake by tumor cells; the siRNAs moieties are subsequently released once inside the cell. The siRNAs bind to PKN3 mRNAs, which may result in the inhibition of translation and expression of the PKN3 protein and, so, growth inhibition of tumor cells that overexpress PKN3. The protein kinase C-related molecule PKN3, downstream in the phosphoinositide-3-kinase (PI3K) signaling pathway, is upregulated in many tumor cells and plays an important role in invasive cell growth and metastasis. 